\title{
Emerging Role of Non-Coding RNAs in Esophageal Squamous Cell Carcinoma
}

\author{
Qingqing Feng ${ }^{1}$, Hongli Zhang ${ }^{1}$, Denglin Yao ${ }^{1}$, Wei-Dong Chen ${ }^{2,3, *}$ and Yan-Dong Wang ${ }^{1, *}$ \\ 1 State Key Laboratory of Chemical Resource Engineering, College of Life Science and Technology, Beijing \\ University of Chemical Technology, Beijing 100029, China; Fengqing910524@163.com (Q.F.); \\ hlz13084@163.com (H.Z.); darrinyao@outlook.com (D.Y.) \\ 2 Key Laboratory of Molecular Pathology, School of Basic Medical Science, Inner Mongolia Medical University, \\ Hohhot 010110, China \\ 3 Key Laboratory of Receptors-Mediated Gene Regulation and Drug Discovery, School of Medicine, Henan \\ University, Kaifeng 475004, China \\ * Correspondence: wdchen666@163.com (W.-D.C.); ydwangbuct2009@163.com (Y.-D.W.)
}

Received: 14 October 2019; Accepted: 14 December 2019; Published: 30 December 2019

\begin{abstract}
Esophageal squamous cell carcinoma (ESCC) is a highly prevalent tumor and is associated with ethnicity, genetics, and dietary intake. Non-coding RNAs (ncRNAs), specifically microRNAs (miRNAs), long ncRNAs (lncRNAs), and circular RNAs (circRNAs) have been reported as functional regulatory molecules involved in the development of many human cancers, including ESCC. Recently, several ncRNAs have been detected as oncogenes or tumor suppressors in ESCC progression. These ncRNAs influence the expression of specific genes or their associated signaling pathways. Moreover, interactions of ncRNAs are evident in ESCC, as miRNAs regulate the expression of lncRNAs, and further, lncRNAs and circRNAs function as miRNA sponges to compete with the endogenous RNAs. Here, we discuss and summarize the findings of recent investigations into the role of ncRNAs (miRNAs, lncRNAs, and circRNAs) in the development and progression of ESCC and how their interactions regulate ESCC development.
\end{abstract}

Keywords: ncRNA; miRNAs; lncRNAs; circRNAs; ESCC

\section{Introduction}

Esophageal cancer (EC) is the eighth most prevalent malignant tumor and sixth leading cause of cancer-related death worldwide [1,2]. The occurrence rate of EC varies depending upon geographical location and esophageal squamous cell carcinoma (ESCC) is observed to be the most prevalent type of EC [3]. Pathogenesis of ESCC is related to ethnicity, genetics, and dietary intake [4]. Consistent with other cancers, ESCC is characterized by epigenetic abnormalities and dysregulation in the signaling pathways [3]. Chemotherapy, radio-chemotherapy, and esophagectomy are the predominant therapeutic strategies for ESCC. However, the 5-year survival rate is still poor $(<15 \%)[5,6]$. Thus, it is of high importance to understand the pathogenetic mechanisms of ESCC and develop effective strategies to treat ESCC.

Recently, non-coding RNAs (ncRNAs) have gained attention as a potential tool for treating different cancers, including ESCC $[7,8]$. Conventional transcriptome studies focus on protein-coding genes. However, more than $90 \%$ of the mammalian genome has been reported to be composed of ncRNAs [9]. Typically, ncRNAs can be divided into housekeeper and regulatory ncRNAs. Housekeeper ncRNAs are commonly referred to transfer RNAs, ribosomal RNAs, small cytoplasmic RNAs, and small nuclear RNAs [10]. The regulatory ncRNAs are broadly subcategorized into microRNAs (miRNAs, 18-25 nt), small interfering RNAs (siRNAs, $<200 \mathrm{nt}$ ), piwi-interacting RNAs (piRNAs, <200 nt), 
and long noncoding RNAs (lncRNAs, $>200 \mathrm{nt}$ ) [11]. Emerging studies on regulatory ncRNAs have shown their role as biomarkers or physiological regulators in many types of cancers, such as breast cancer, osteosarcoma, lung cancer, hepatocellular carcinoma, cervical cancer, bladder cancer [12-16]. Moreover, there have been increased investigations into the role of ncRNAs in ESCC [17-19]. Chen et al. revealed that IncRNA FAM201A increases radiosensitivity of ESCC by downregulating miR-101 while upregulating ataxia telangiectasia mutated (ATM) and mammalian target of rapamycin (mTOR) [20]. Thus, investigating the functions of ncRNAs and understanding their regulatory mechanism in ESCC is crucial for the further development of effective strategies to treat ESCC.

Circular RNAs are considered to be a special type of lncRNA, and display little susceptibility to exonucleases, resulting in a high stability. [21]. They were first discovered in 1976; however, they were re-established by RNA sequencing in 2012 [22,23]. Emerging publications have proposed the roles of circRNAs as biomarkers and physiological regulators in the development and progression of cancer [24]. The biological functions of circRNAs have mainly been reported as miRNA sponging and transcription regulation $[25,26]$. These characteristics and functions of circRNAs have contributed to its roles in the biology of human cancers, including ESCC [27,28].

In this review, we summarize the regulatory functions of ncRNAs in ESCC. Additionally, we highlight novel functions of ncRNAs that contribute to the development of malignant phenotypes of ESCC, and how such interactions between ncRNAs influence ESCC (Figure 1).

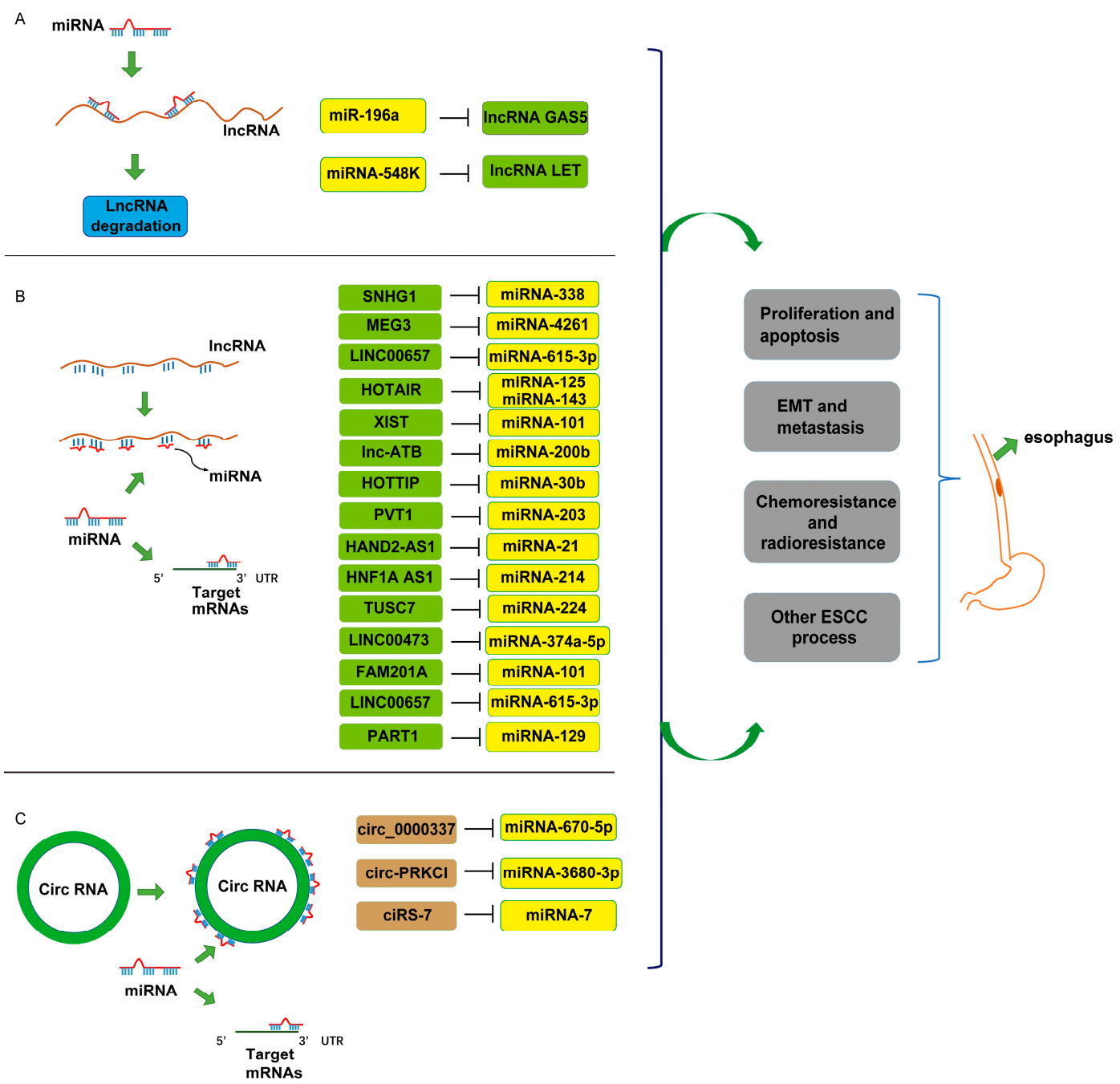

Figure 1. Non-coding RNA (NcRNA) regulatory interaction in esophageal squamous cell carcinoma 
Figure 2. (ESCC) progression. (A) MicroRNAs (miRNAs) can directly target long ncRNA (lncRNA) and regulate lncRNA expression in ESCC progression. (B) Long ncRNAs work as miRNA sponge to compete with endogenous RNAs. (C) Circular RNAs (circRNAs) release target mRNAs by competitively binding with miRNAs. These ncRNA interactions are involved in ESCC cell proliferation, apoptosis, epithelial-mesenchymal transition (EMT), metastasis, chemoradiotherapy, and other ESCC processes.

\section{Role of Non-Coding RNAs in ESCC Progression}

To understand the role of ncRNAs in ESCC progression, numerous investigations on ncRNAs (mainly miRNAs and lncRNAs) in ESCC have been reported [7,8,29-31]. Many studies on the regulation of circRNAs in ESCC are in their early stages. However, there is the possibility that circRNAs may become novel potential targets for ESCC treatment. A previous report showed that Spatholobi Caulis tannin mediates several related circRNAs to suppress cell proliferation and promote apoptosis in cervical cancer [32]. In ESCC, ncRNAs have been suggested to play roles as oncogenes or tumor suppressors to regulate ESCC proliferation, apoptosis, epithelial-mesenchymal transition (EMT), metastasis, chemotherapy, or radiotherapy [33-37]. Additionally, several ncRNAs have been observed to serve as prognostic markers in patients with ESCC [5,38]. Several studies which suggest the role and mechanism of ncRNAs in the development of ESCC have been summarized in Table 1.

Table 1. Regulatory non-coding RNAs (ncRNAs) in ESCC progression.

\begin{tabular}{|c|c|c|c|c|}
\hline $\begin{array}{l}\text { Role of ncRNAs } \\
\text { in ESCC }\end{array}$ & ncRNAs & $\begin{array}{l}\text { Identified TARGETS or Signaling } \\
\text { Pathways }\end{array}$ & Role & Reference \\
\hline \multirow{28}{*}{$\begin{array}{l}\text { Cell proliferation } \\
\text { and apoptosis }\end{array}$} & miRNA: & & & \\
\hline & miRNA-146a & IRS2 & - & [29] \\
\hline & miRNA-133b & TAGLN2 & - & [39] \\
\hline & miRNA-106b-3p & ZNRF3 & - & [33] \\
\hline & miRNA-219-5p & CCNA2 & - & {$[40]$} \\
\hline & miRNA-206 & c-MET & - & [41] \\
\hline & miRNA-384 & LIMK1 & - & [42] \\
\hline & miRNA-455-5p & Rab31 & - & [43] \\
\hline & miRNA-128 & $\mathrm{COX} 2$ & - & {$[44]$} \\
\hline & miRNA $1453 p, 5 p$ & DHRS2 and MYO1B, Sp1 & - & {$[45,46]$} \\
\hline & miRNA-10b-3p & FOXO3 & - & {$[47]$} \\
\hline & miRNA-874-3p & STAT3 & - & [48] \\
\hline & miRNA-10a & Tiam1 & - & [49] \\
\hline & miRNA-365 & PSAT1 & - & [50] \\
\hline & miRNA-301a & WNT1 & - & [51] \\
\hline & miRNA-6775-3p & MAGE-A and SLC7A5 & - & {$[52]$} \\
\hline & miRNA-139-5p & VEGFR & - & [53] \\
\hline & miRNA-516b & CCNG1 & - & [54] \\
\hline & miRNA-449a-5p & Cyclin D1 & - & [55] \\
\hline & miRNA-125b & BMF & - & [56] \\
\hline & miRNA-433-3p & GRB2 & - & [57] \\
\hline & miRNA-370 & PIN1 & - & [58] \\
\hline & miRNA-133b & Cullin 4B & - & [35] \\
\hline & miRNA-1 & Notch2 & - & [59] \\
\hline & miRNA-30a-3p, $5 p$ & Wnt2, FZD2 & - & [60] \\
\hline & miRNA-34a & PLCE1 & - & [61] \\
\hline & miRNA-196a & lncRNA GAS5 & - & [62] \\
\hline & miRNA-125b-5p & HMGA2 & - & [63] \\
\hline
\end{tabular}


Table 1. Cont.

\begin{tabular}{|c|c|c|c|c|}
\hline $\begin{array}{l}\text { Role of ncRNAs } \\
\text { in ESCC }\end{array}$ & ncRNAs & $\begin{array}{c}\text { Identified TARGETS or Signaling } \\
\text { Pathways }\end{array}$ & Role & Reference \\
\hline \multirow{49}{*}{$\begin{array}{l}\text { Cell proliferation } \\
\text { and apoptosis }\end{array}$} & miRNA: & & & \\
\hline & miRNA-141 & YAP1 and SOX17 & + & {$[64]$} \\
\hline & miRNA-21 & RASA1 & + & [65] \\
\hline & miRNA-424 & PRKCD and WEE1 & + & {$[66]$} \\
\hline & miRNA-675-3p & NA & + & [67] \\
\hline & miRNA-543 & PLA2G4A & + & [68] \\
\hline & miRNA-135 & RERG & + & [69] \\
\hline & miRNA-23b-3p & EBF3 & + & [70] \\
\hline & miRNA-502 & NA & + & [71] \\
\hline & miRNA-21-5p & CADM2 & + & {$[72]$} \\
\hline & miRNA-548k & lncRNA-LET & + & [73] \\
\hline & LncRNAs: & & & \\
\hline & LncRNA SNHG1 & miRNA-338/CST3,Notch signaling & + & {$[74,75]$} \\
\hline & LncRNA SNHG6 & NA & + & {$[76]$} \\
\hline & LncRNA SNHG16 & Wnt/ $\beta$-catenin,miRNA-140-5p/ZEB & + & {$[77,78]$} \\
\hline & LncRNA MEG3 & miRNA-4261 & + & {$[79]$} \\
\hline & LINC01980 & GADD45A & + & [80] \\
\hline & $\begin{array}{l}\text { FMR1-AS1 (female } \\
\text { patients) }\end{array}$ & TLR7 & + & [81] \\
\hline & DLX6AS1 & NA & + & [82] \\
\hline & LINC00657 & miRNA-615-3p & + & [83] \\
\hline & DUXAP10 & p21 & + & [84] \\
\hline & LINC01296 & NA & + & [85] \\
\hline & LncRNA DANCR & NA & + & [86] \\
\hline & LncRNA SOX2OT & NA & + & [87] \\
\hline & LncRNA NMR & BPTF/ ERK1/2 pathway & + & [88] \\
\hline & MIR31HG & NA & + & [89] \\
\hline & AK001796 & p53 & + & [90] \\
\hline & LINC01503 & EBP1 and DUSP6 & + & [91] \\
\hline & LUCAT1 & DNMT1 & + & [92] \\
\hline & Linc ROR & SOX9 & + & [93] \\
\hline & HOTAIR & miRNA-125 and miRNA-143 & + & [94] \\
\hline & XIST & miRNA-101/EZH2 & + & [95] \\
\hline & LncRNA GHET1 & EMT & + & [96] \\
\hline & Lnc-ATB & miRNA-200b/Kindlin-2 & + & [97] \\
\hline & HOTTIP & miRNA-30b/snail1, HOXA13 & + & [98] \\
\hline & PVT1 & miRNA-203/LASP1 & + & [99] \\
\hline & AFAP1-AS1 & NA & + & {$[37]$} \\
\hline & LINC00675 & Wnt $/ \beta$-catenin & - & [83] \\
\hline & HAND2-AS1 & miRNA-21 & - & [100] \\
\hline & LncRNA NEF & Wnt/ $\beta$-catenin pathway & - & [101] \\
\hline & LncRNA GAS5 & PI3K/AKT/mTOR & - & [102] \\
\hline & FER1L4 & NA & - & [103] \\
\hline & \multicolumn{4}{|l|}{ CircRNAs: } \\
\hline & Circ_0000337 & miRNA-670-5p & + & [18] \\
\hline & Circ-PRKCI & miRNA-3680-3p & + & [27] \\
\hline & CircRNA_100876 & NA & + & {$[28]$} \\
\hline & Circ-DLG1 & miRNAs & + & [104] \\
\hline & CiRS-7 & miRNA-7/KLF4 and NF- $k B$ signals & + & [105] \\
\hline & Circ_0067934 & NA & + & [106] \\
\hline
\end{tabular}


Table 1. Cont.

\begin{tabular}{|c|c|c|c|c|}
\hline $\begin{array}{l}\text { Role of ncRNAs } \\
\text { in ESCC }\end{array}$ & ncRNAs & $\begin{array}{l}\text { Identified TARGETS or Signaling } \\
\text { Pathways }\end{array}$ & Role & Reference \\
\hline \multirow{33}{*}{$\begin{array}{l}\text { Cell EMT and } \\
\text { metastasis }\end{array}$} & miRNA: & & & \\
\hline & miRNA-106b-3p & ZNRF3 & - & {$[33]$} \\
\hline & miRNA-455-5p & Rab31 & - & [43] \\
\hline & miRNA-128 & $\operatorname{cox} 2$ & - & {$[44]$} \\
\hline & miR-128-3p & ZEB1 & - & [107] \\
\hline & miRNA-10a & Tiam1 & - & [49] \\
\hline & miRNA-6775-3p & MAGE-A and SLC7A5 & - & [52] \\
\hline & miRNA-139-5p & VEGFR & - & [53] \\
\hline & miRNA-30c & SNAI1 & - & [108] \\
\hline & miRNA-25 & NA & - & [109] \\
\hline & miRNA-34a & PLCE1, CD44 & - & {$[61,110]$} \\
\hline & miRNA-31 & LATS2 & - & [111] \\
\hline & miRNA-145-5p & $\mathrm{Sp} 1$ & - & [45] \\
\hline & miRNA-377 & CD133 and VEGF & - & [112] \\
\hline & miRNA-543 & PLA2G4A & + & [68] \\
\hline & miRNA-23b-3p & EBF3 & + & {$[70]$} \\
\hline & miRNA-25 & FBXW7 & + & [109] \\
\hline & miR-99b/let-7e/miR-125a & ARID3A & + & [113] \\
\hline & LBX2-AS1 & ZEB1 and ZEB2 & + & [114] \\
\hline & LncRNA-ECM & ICAMI & + & [115] \\
\hline & FTH1P3 & $\mathrm{SP} 1 / \mathrm{NF}-\mathrm{kB}$ & + & [116] \\
\hline & NMR & BPTF/ ERK1/2 pathway & + & [88] \\
\hline & Linc-UBC1 & EZH2 and E-cadherin & + & [117] \\
\hline & CASC9 & CBP and LAMC2 & + & [118] \\
\hline & LincRNA-ROR & miR-145/FSCN1 & + & [119] \\
\hline & SNHG16 & miR-140-5p/ZEB1 & + & [77] \\
\hline & LncRNA SNHG1 & Notch signaling & + & [74] \\
\hline & LncRNA GHET1 & EMT & + & [96] \\
\hline & HNF1A-AS1 & miR 214/SOX-4 & + & [120] \\
\hline & Lnc-ATB & miR-200b/Kindlin-2 & + & [97] \\
\hline & HOTTIP & WDR5 and HOXA13 & + & {$[98,121]$} \\
\hline & LINC00675 & $\mathrm{Wnt} / \beta$-catenin & - & [83] \\
\hline & RP11-766N7.4 & NA & - & [122] \\
\hline \multirow{10}{*}{$\begin{array}{l}\text { Chemosensitivity } \\
\text { and } \\
\text { radiosensitivity }\end{array}$} & miRNA: & & - & \\
\hline & $\begin{array}{c}\text { miRNA-29c } \\
\text { (5-fluorouracil) }\end{array}$ & F-box only protein 31 & - & [123] \\
\hline & $\begin{array}{c}\text { miR-130a-3p and } \\
\text { miR-148a-3 } \\
\text { (Cisplatin and } \\
\text { 5-FU) }\end{array}$ & $\mathrm{Bcl}-2 / \mathrm{Bim}$ and $\mathrm{Bcl}$ /XIAP & - & [34] \\
\hline & $\begin{array}{l}\text { miRNA-125a-5p } \\
\text { (cisplatin) }\end{array}$ & STAT3 signaling & - & [124] \\
\hline & $\begin{array}{l}\text { miRNA-1 } \\
\text { (gefitinib) }\end{array}$ & PIK3CA signaling & - & [125] \\
\hline & $\begin{array}{l}\text { miRNA-338-5p } \\
\text { (radiosensitivity) }\end{array}$ & Apoptosis signaling & - & [36] \\
\hline & $\begin{array}{c}\text { miRNA-200c } \\
\text { (radiosensitivity) }\end{array}$ & Cell cycle arrest and p21 & - & [126] \\
\hline & $\begin{array}{l}\text { LncRNA TUSC7 } \\
\text { (cisplatin or 5-Fu) }\end{array}$ & miRNA-224/DESC1 & - & [127] \\
\hline & $\begin{array}{l}\text { LINC01419 } \\
\text { (5-fluorouracil) }\end{array}$ & GSTP1 methylation & + & [5] \\
\hline & $\begin{array}{l}\text { LINC00473 } \\
\text { (radiotherapy) }\end{array}$ & miRNA-374a-5p & + & [38] \\
\hline
\end{tabular}


Table 1. Cont.

\begin{tabular}{|c|c|c|c|c|}
\hline $\begin{array}{l}\text { Role of ncRNAs } \\
\text { in ESCC }\end{array}$ & ncRNAs & $\begin{array}{c}\text { Identified TARGETS or Signaling } \\
\text { Pathways }\end{array}$ & Role & Reference \\
\hline \multirow{6}{*}{$\begin{array}{l}\text { Chemosensitivity } \\
\text { and } \\
\text { radiosensitivity }\end{array}$} & miRNA: & & - & \\
\hline & $\begin{array}{l}\text { Linc-VLDLR in } \\
\text { extracellular } \\
\text { vesicles } \\
\text { (adriamycin) }\end{array}$ & NA & + & [128] \\
\hline & $\begin{array}{l}\text { LnRNA FAM201A } \\
\text { (radiotherapy) }\end{array}$ & miRNA-101/ATM and mTOR & + & {$[20]$} \\
\hline & $\begin{array}{l}\text { LINC00657 } \\
\text { (radiotherapy) }\end{array}$ & miRNA-615-3p and JunB & + & [129] \\
\hline & $\begin{array}{l}\text { LncRNA PART1 } \\
\text { (gefitinib) }\end{array}$ & miRNA-129/Bcl-2 pathway & + & [130] \\
\hline & $\begin{array}{c}\text { MALAT1 } \\
\text { (radiotherapy) }\end{array}$ & Cks1 & + & {$[131]$} \\
\hline \multirow[t]{2}{*}{$\begin{array}{l}\text { Prognostic } \\
\text { biomarkers }\end{array}$} & miRNA-506, miRN & $\begin{array}{l}\text { miRNA: } \\
\text {-145, miRNA-375, miRNA-655, miRN } \\
\text { miRNA-9 } \\
\text { LncRNA: }\end{array}$ & $874-3 p$ & $\begin{array}{l}{[48,132-} \\
135]\end{array}$ \\
\hline & $\begin{array}{l}\text { MEG3, SEMA3B-A } \\
\text { and MALA }\end{array}$ & $\begin{array}{l}\text { 1, SNHG6, AK001796, ANRIL, BANC } \\
\text { 1, MIR31HG, FOXD2-AS1, LINC012 }\end{array}$ & UCA1 & $\begin{array}{l}{[76,79,85,89,} \\
90,136-139]\end{array}$ \\
\hline \multicolumn{5}{|c|}{$\begin{array}{l}\text { +, Oncogene; -, a tumor suppressor; NA, not available. EMT, epithelial-mesenchymal transition; IRS2, insulin } \\
\text { receptor substrate 2; TAGLN2, transgelin-2; ZNRF3, zinc and ring finger 3; CCNA2, cyclin A2; LIMK1, LIM domain } \\
\text { kinase 1; DHRS2, dehydrogenase/reductase member 2; MYO1B, myosin IB; Tiam1, T-lymphoma invasion and } \\
\text { metastasis protein inducing protein 1; PSAT1, phosphoserine aminotransferase 1; SLC7A5, solute carrier family } 7 \\
\text { member 5; BMF, BCL-2-modifying factor; GRB2, growth factor receptor-bound protein 2; PIN1, peptidyl-prolyl } \\
\text { cis-trans isomerase NIMA-interacting 1; PLCE1, phospholipase C elipson 1; HMGA2, high mobility group protein A2; } \\
\text { RASA1, RAS p21 protein activator 1; YAP1, yes- associated protein 1; SOX17, SRY-box 17; PLA2G4A, phospholipase } \\
\text { A2 group IVA; RERG, RAS like estrogen regulated growth inhibitor; GADD45A, DNA damage inducible } 45 \text { alpha; } \\
\text { BPTF, bromodomain PHD finger transcription factor; DNMT1, DNA methyltransferase 1; PLCE1, phospholipase C } \\
\text { elipson 1; LATS2, large tumor suppressor kinase 2; ARID3A, AT-rich interaction domain 3A; FBXW7, F-box and WD } \\
\text { repeat domain-containing 7: BPTE bromodomain PHD finger transcription factor. }\end{array}$} \\
\hline
\end{tabular}

\section{Non-Coding RNAs Regulate Cell Proliferation and Apoptosis during ESCC Development}

The capability to regulate cell proliferation and apoptosis is crucial in cancer therapy. Various publications have shown that ncRNAs, such as miRNAs and lncRNAs, mediate ESCC cell proliferation and cell apoptosis or function mutually to regulate cell migration and invasion [59,64,82].

MicroRNAs control ESCC development by directly binding to mRNAs, which results in the translation repression of mRNAs [140]. During the past two years, a large number of miRNAs have been revealed to be functional regulators of cell proliferation and apoptosis (Table 1). For example, Liu et al. reported that miR-1 expression is downregulated in ESCC tissue and plasma compared to miR-1 expression in matching adjacent normal tissues. Furthermore, they found that miR-1 may inhibit ESCC development via directly targeting $3^{\prime}$-UTR of neurogenic locus notch homolog protein 2 (Notch2) thereby suppressing cell proliferation, migration, and invasion [59]. In addition, miRNAs have been suggested to function as mediators for other drugs to control ESCC progression. MicroRNA-30d was observed to be upregulated which may be directly suppressing PI3K regulatory subunit 2 (PIK3R2). Additionally, the effects caused by PI3K/AKT signaling inhibition, apoptosis and cell cycle arrest have been reported to have been partially restored by anti-miRNA-30d [141]. Many such studies have been published so far, which reveal miRNAs as tumor suppressors or oncogenes (Table 1). For example, miR-146a, miR-133b, miR-106b-3p, miR-219-5p, miR-206, miR-384, miR-455-5p, miR-128, miR-145-3p/5p, miR-10b-3p, miR-874-3p, miR-10a, miR-365, miR-301a, miR-6775-3p, miR-139-5p, miR-516b, miR-449a-5p, miR-125b, miR-433-3p, miR-370, miR-133b, miR-30a-3p/5p, miR-34a, miR-196a, and miR-125b-5p have been shown to act as tumor suppressors by inhibiting ESCC cell proliferation, promoting apoptosis by directly targeting oncogenes, or antagonizing pro-cancer 
signaling pathways $[29,33,35,40-52,54-58,60-63,110,133]$. In contrast, pro-oncogenes such as miR-141, miR-21, miR-10b-3p, miR-424, miR-675-3p, miR-543, miR-135, miR-23b-3p, miR-502, miR-21-5p, and $\mathrm{miR}-548 \mathrm{k}$ have been reported to play contrasting roles in promoting cell proliferation or suppressing apoptosis in ESCC [47,64-73]. Overall, the roles of miRNAs in cell proliferation and apoptosis can be crucial in ESCC pathogenesis.

Long ncRNAs can function as gene regulators by interacting with DNA (e.g., as promoters), RNA, or proteins [142]. Accumulating evidence has proposed that lncRNAs play a significant role in the biological development of ESCC, such as in the regulation of cell proliferation and apoptosis [7,143]. For instance, IncRNA small nucleolar host gene 1 (SNHG1), SNHG6, and SNHG16 have been reported to promote ESCC cell proliferation [74-78]. The lncRNA SNHG16 promotes ESCC proliferation through activating Wnt $/ \beta$-catenin signaling and targeting miR-140-5p/zinc finger E-box binding homeobox 1 (ZEB1) axis [77,78]. Long ncRNA SNHG1 is upregulated in ESCC tissues and high expression of SNHG1 can be positively correlated with ESCC lymph node metastasis and decreased overall survival. Furthermore, it has been reported that silencing lncRNA SNHG1 inhibits ESCC cell proliferation and EMT capability via antagonizing Notch signaling [74]. Yan et al. have described lncRNA SNHG1 as a promoter of ESCC cell proliferation. They showed that SINHG1 directly interacts with miR-338 and competes with it, directly targeting proto-oncogene cystatin $\mathrm{C} 3$ and plays a role as a tumor suppressor in ESCC cells [75]. These studies demonstrate that the mechanisms of lncRNAs in ESCC are not specific. Long ncRNA colon cancer-associated transcript 1 (CCAT1) has been shown to undergo different mechanisms in nucleus and cytoplasm, and thereby promote cell growth and migration. In the nucleus of the ESCC cell, CCAT1 functions as a suppressor of sprout RTK signaling antagonist 4 (SPRY4) by linking the enhancer of zeste homolog 2 (EZH2) and the suppressor of variegation 3-9 homolog 1 (SUV39H). Inversely, CCAT1 has been shown to promote homeobox B13 (HOXB13) expression by functioning as an miR-7 sponge in the cytoplasm [31]. Thus, varying results suggest that lncRNAs may be inhibiting or promoting ESCC development by different mechanisms. The role of lncRNAs in ESCC cell proliferation and apoptosis has been extensively studied and the findings of a few relevant studies are summarized in Table 1.

As a novel category of ncRNAs, investigations on the role of circRNAs in ESCC development are still in its initial stages $[18,144]$. Compared with adjacent non-cancerous tissues, several circRNAs, such as circ-0067934, circ-PRKCI, circRNA-100876, circ-DLG1, and ciRS-7, have been observed to be significantly upregulated in ESCC tissues. Moreover, circ-0067934, circ-PRKCI, circRNA-100876, and circ-DLG1 have been reported to induce cell proliferation, ciRS-7 enhanced cell migration, and invasion abilities in the progression of ESCC $[18,27,28,104,105]$. Thus, the role of circRNAs in ESCC should be further investigated, which may provide novel strategies for ESCC treatment.

\section{Non-Coding RNAs and EMT and Metastasis in ESCC}

During cancer development, malignant tumors and $>90 \%$ of cancer-related deaths are characterized by cells of epithelial origin, which have invaded neighboring or distant tissues and organs where they promote the formation of secondary tumors [145]. EMT involves transformation of polarized epithelial cells into mesenchymal phenotype with high motility and thus, it is an essential cellular process for tumor metastasis [146]. As a result, understanding and targeting ncRNAs to suppress EMT and tumor metastasis is a potential course of action for inhibiting the progression of cancer malignancy.

Meng et al. showed that high expression levels of miR-6775-3p are positively correlated with good clinical outcomes. In vivo studies have shown that miR-6775-3p inhibits liver metastasis of ESCC by binding to the 3'-UTR of the melanoma antigen gene A (MAGE-A) family of tumor antigens [52]. Furthermore, miR-30c has been known to impair EMT capabilities of cells by directly targeting snail family transcriptional repressor 1 (SNAI1) in ESCC [108]. Thus, the regulatory mechanisms of miRNAs for EMT and tumor metastasis are diverse. Studies have reported that miR-34a functions as an EMT inhibitor as it reduces the intensity of ESCC progression by binding to phospholipase C elipson 1 (PLCE1) [61]. In another study on ESCC progression, overexpression of miR-34a was 
found to decrease the number of metastatic nodules in the liver via directly targeting CD44 [110]. At present, various miRNAs have been found to regulate EMT or tumor metastasis of ESCC. It has been reported that miR-106b-3p, miR-455-5p, and miR-128 function as tumor suppressors, and have suppressed EMT or metastasis in ESCC [33,43,44]. While miRNAs, such as miR-543, miR-23b-3p, miR-25, and miR-99b/let-7e/miR-125a play oncogenic roles in promoting EMT or metastasis during ESCC progression $[68,70,109,113]$. These miRNAs could serve as promising therapeutic targets in ESCC development.

Unlike miRNAs, most lncRNAs promote EMT and tumor metastasis in ESCC. The expression of LBX2-AS1 was found to be upregulated in ESCC metastatic tissues. In terms of mechanism, lncRNA LBX2-AS1 enhances ZEB1 and ZEB2 mRNA stability by interacting with RNA-binding protein heterogeneous nuclear ribonucleoprotein C (HNRNPC). Consecutively, ZEB1 may function as a transcriptional activator and activate LBX2-AS1. Due to such interactions, IncRNA LBX2-AS1 can contribute to the malignant progression of ESCC by promoting tumor migration and EMT [114]. Similarly, IncRNA-ECM, IncRNA-FTH1P3, and IncRNA-NMR have been reported to exacerbate the malignant progression of ESCC by promoting EMT or tumor metastasis $[88,115,116]$. Some anti-oncogenic lncRNAs such as LINC00675 and RP11-766N7.4 may inhibit EMT in ESCC [83,122]. Overall, these lncRNAs have the potential to be therapeutic targets to delay the malignant progression of ESCC by inhibiting EMT and tumor metastasis.

\section{Non-coding RNAs Influence Chemoresistance and Radioresistance in ESCC}

Among the therapeutic strategies for ESCC, chemotherapy, chemoradiotherapy, and esophagectomy are the primary treatments. However, the 5-year survival rate is observed to be still poor [147]. This poor prognosis might be due to chemoresistance and radioresistance developed by ESCC cells $[36,124]$. In this case, ncRNAs may increase or decrease chemoresistance and radioresistance in the treatment of ESCC $[148,149]$.

Regulating miRNAs as a sensitive therapy is a new prospect in ESCC treatment. Studies have reported that miR-338-5p and miR-200c enhance the radiosensitivity of ESCC by inducing apoptosis and cell cycle arrest in tumor cells, respectively [36,126]. Similarly, miR-29c, miR-125a-5p, and miR-1 enhance ESCC cell sensitivity for anticancer drugs such as 5-fluorouracil, cisplatin, and gefitinib, respectively [123-125]. As shown in Table 1, these reported miRNAs target different molecules or signaling pathways to decrease chemoresistance and radioresistance in ESCC. Specifically, Eichelmann et al. found that overexpression as well as knockdown of miR-130a-3p and miR-148a-3p increased the sensitivity of ESCC cells towards chemotherapeutic drugs, cisplatin and 5-fluorouracil. Furthermore, the overexpression and knockdown of the two miRNAs inhibited cell migration and induced apoptosis in ESCC cells which was different from the conventional miRNA regulatory mechanism. In brief, overexpression as well as knockdown of miR-148a-3p activated p53-dependent apoptosis by inducing $\mathrm{Bcl} 2$-associated protein X (BAX) levels. However, it was found to differentially mediate the expression levels of pro-apoptotic Bcl2-like protein 11 (BIM) and anti-apoptotic B-cell lymphoma 2 (BCL2). Researchers observed that overexpression of miR-148a-3p leads to significant inhibitory expression of BCL2 compared to suppression of BIM. However, when miR-148a-3p was downregulated, BIM was observed to be noticeably upregulated compared to the upregulation of BCL2. Furthermore, miR-130a-3p showed similar regulatory effects for BCL2 and X-linked inhibitor of apoptosis protein (XIAP) [34]. Balancing the regulation of several target genes is critical for an efficient response of miRNAs towards chemotherapy in ESCC. These reports reveal that miRNAs participate in the decrease of chemoresistance and radioresistance in ESCC, thereby providing a novel strategy for ESCC treatment.

In ESCC, several lncRNAs function as mediators of gene expression or signaling pathways that are involved in chemoresistance and radioresistance $[5,20,38,127]$. LINC00473, IncRNA FAM201A, and LINC00657 impair the effect of radiotherapy by acting as sponges for miRNAs [20,38,129]. Long ncRNA TUSC7 suppresses cisplatin and 5-fluorouracil resistance in ESCC cells by inhibiting miR-224. Overexpression of LINC01419 is observed to promote GSTP1 methylation by binding to the 
promoter region of the GSTP1 in ESCC cells and reduce the sensitivity of ESCC cells to 5-fluorouracil [5]. Non-coding RNAs derived from donor cell cytoplasm can be transferred to recipient cells through extracellular vesicles (EVs). Chen et al. found that linc-VLDLR, when transported by the EVs, is responsible for adriamycin resistance in ESCC cells by upregulating ATP binding cassette G2 (ABCG2) in target cells [128]. Gefitinib, an ATP competitive selective EGFR tyrosine kinase inhibitor, has been investigated in ESCC clinical studies. Kang et al. showed that lncRNA PART1 and STAT1 is highly expressed in gefitinib-resistant ESCC cells. In addition, STAT1 may function as an inducer of lncRNA PART1 by binding to its promoter region. Furthermore, PART1 may act as a sponge for miR-129 to upregulate BCL2 expression and promote gefitinib resistance in ESCC. Thus the study has revealed that an exosome can carry PART1 as cargo and transport it to sensitive recipient cells which contribute to increasing gefitinib resistance. Consistency has been observed with results of clinical research that showed that the efficacy of gefitinib treatment is worse in patients with ESCC and high expression of PART1 in serum exosome [130]. These results suggest that lncRNAs can increase or decrease chemoresistance or radioresistance, and EV-mediated lncRNAs might be transmitting chemoresistance in ESCC. Thus, such investigations on lncRNAs provide the foundation for the clinical treatment of ESCC and lncRNAs may be useful as diagnostic biomarkers.

Currently, growing investigations have revealed that functions of ncRNAs in the ESCC progression such as proliferation, EMT, and resistance cannot be ignored. However, ncRNA biology therapy of ESCC is still in the preclinical stage. The pharmacodynamics and safety of ncRNA therapy in ESCC need to be further validated by clinical trials.

\section{Experimental Approaches of Studying Non-Coding RNAs in ESCC}

Identification of aberrant ncRNAs expression in ESCC tissues is of primary importance for studying the function of ncRNAs in ESCC. Quantitative real-time PCR (q-PCR) is a classic method for detecting aberrant ncRNA expression in ESCC tissues [18,52,76]. In recent years, available microarray and next generation sequencing (NGS) techniques bring researchers more complete ncRNA expression profiles between ESCC tumor and normal tissue $[5,88,118]$. For example, Wang et al. detected 402 upregulated and 741 downregulated lncRNAs in ESCC tumors and adjacent normal tissues from ESCC patients by NGS [150].

In vitro studies on the function of ncRNAs in ESCC are generally based on overexpression or knockdown of an ncRNA in ESCC cell lines. Overexpression plasmid or small interfering miRNA mimics and inhibitors are commonly used for transient overexpression or knockdown of miRNAs in ESCC cells $[34,52,107]$. RNA interference (RNAi), mainly involving siRNA and short hairpin RNA (shRNA), has been widely applied in knockdown of ncRNAs in ESCC cells $[18,27,31,80]$. However, the effectiveness of overexpression plasmid, siRNAs, miRNA mimics, and inhibitors is limited. After $48 \mathrm{~h}$ of administration, less than $1 \%$ of the siRNA remained in the cells. Short hairpin RNA is sufficient to provide continual gene knockdown effects because it can be continuously synthesized in the host cells [151]. To ascertain the role of LINC01419 in ESCC, Chen et al. performed a knockdown of LINC01419 expression in ESCC cells using shRNA in vitro and in vivo. In xenograft models of ESCC, lentiviral vectors are common used for delivery of exogenous DNA because of their high transfection efficiency and effective integration [31,151,152]. A xenograft model can be established by direct injection of stably transfected ESCC cell lines into recipient mice. For example, Liang et al. identified the contributory role of LncRNA CASC9 in ESCC metastasis by transfecting CASC9 siRNAs or overexpression plasmid of CASC9 in vitro. In an in vivo study, KYSE150 cells stably infected with CASC9 siRNA lentiviral vector (LV-CASC9) were given to BALB/c mice by a tail vein injection [153]. At present, siRNA and shRNA still have certain off-target effects and safety problems and lentivirus vector also has certain safety and immunogenicity risks [151]. Therefore, the development and optimization of safe and effective ncRNA interference technology and delivery systems may benefit for research into the functions of ncRNAs in ESCC. 


\section{Prospects}

Over a decade of research has improved our understanding of ncRNAs, from transcriptional noises to functional regulatory molecules that mediate diverse physiological and pathological processes [142,154]. Investigating the functions and mechanisms of ncRNAs provides potential therapeutic targets in treating many cancers. However, research about circRNAs regulating ESCC is in its initial stage and some mechanisms by which IncRNAs and circRNAs mediate ESCC pathogenesis is poorly known. In conclusion, ncRNAs contribute to the development and prognosis of ESCC. Further investigation of the detailed mechanisms by which ncRNAs regulate ESCC may provide new insights into how ncRNAs promote or inhibit tumor development and provide potential therapeutic targets for treating ESCC.

Funding: This work is supported by the National Natural Science Foundation of China (Grant No. 81672433, No. 81970551 and No. 81370537), the Fundamental Research Funds for the Central Universities and Research projects on biomedical transformation of China-Japan Friendship Hospital (Grant No. PYBZ1803) to Y.-D.W., the National Natural Science Foundation of China (Grant No. 81472232 and No. 81970726), Henan Provincial Natural Science Foundation (Grant No. 182300410323 and No. 182300410316), Program for Science \& Technology Innovation Talents in Universities of Henan Province (HASTIT, Grant No. 13HASTIT024) and Plan for Scientific Innovation Talent of Henan Province to W.-D.C.

Conflicts of Interest: The authors declare no conflict of interest.

\section{References}

1. Kauppila, J.H.; Selander, K.S. Toll-like receptors in esophageal cancer. Front. Immunol. 2014, 5, 200. [CrossRef] [PubMed]

2. Huang, F.L.; Yu, S.J. Esophageal cancer: Risk factors, genetic association, and treatment. Asian J. Surg. 2018, 41, 210-215. [CrossRef] [PubMed]

3. Chen, J.; Kwong, D.L.; Cao, T.; Hu, Q.; Zhang, L.; Ming, X.; Chen, J.; Fu, L.; Guan, X. Esophageal squamous cell carcinoma (ESCC): Advance in genomics and molecular genetics. Dis. Esophagus Off. J. Int. Soc. Dis. Esophagus 2015, 28, 84-89. [CrossRef] [PubMed]

4. Abnet, C.C.; Arnold, M.; Wei, W.Q. Epidemiology of esophageal squamous cell carcinoma. Gastroenterology 2018, 154, 360-373. [CrossRef]

5. Chen, J.L.; Lin, Z.X.; Qin, Y.S.; She, Y.Q.; Chen, Y.; Chen, C.; Qiu, G.D.; Zheng, J.T.; Chen, Z.L.; Zhang, S.Y. Overexpression of long noncoding RNA LINC01419 in esophageal squamous cell carcinoma and its relation to the sensitivity to 5-fluorouracil by mediating GSTP1 methylation. Ther. Adv. Med. Oncol. 2019, 11. [CrossRef]

6. Jackie Oh, S.; Han, S.; Lee, W.; Lockhart, A.C. Emerging immunotherapy for the treatment of esophageal cancer. Expert Opin. Investig. Drugs 2016, 25, 667-677. [CrossRef]

7. Deng, H.Y.; Wang, Y.C.; Ni, P.Z.; Lin, Y.D.; Chen, L.Q. Long noncoding RNAs are novel potential prognostic biomarkers for esophageal squamous cell carcinoma: An overview. J. Thorac. Dis. 2016, 8, E653-E659. [CrossRef]

8. Sundaram, G.M.; Veera Bramhachari, P. Molecular interplay of pro-inflammatory transcription factors and non-coding RNAs in esophageal squamous cell carcinoma. Tumour Biol. J. Int. Soc. Oncodev. Biol. Med. 2017, 39. [CrossRef]

9. Lin, Y.H.; Wu, M.H.; Yeh, C.T.; Lin, K.H. Long non-coding RNAs as mediators of tumor microenvironment and liver cancer cell communication. Int. J. Mol. Sci. 2018, 19, 3742. [CrossRef]

10. Lei, B.; Tian, Z.; Fan, W.; Ni, B. Circular RNA: A novel biomarker and therapeutic target for human cancers. Int. J. Med. Sci. 2019, 16, 292-301. [CrossRef]

11. Memczak, S.; Jens, M.; Elefsinioti, A.; Torti, F.; Krueger, J.; Rybak, A.; Maier, L.; Mackowiak, S.D.; Gregersen, L.H.; Munschauer, M.; et al. Circular RNAs are a large class of animal RNAs with regulatory potency. Nature 2013, 495, 333-338. [CrossRef] [PubMed]

12. Tomar, D.; Yadav, A.S.; Kumar, D.; Bhadauriya, G.; Kundu, G.C. Non-coding RNAs as potential therapeutic targets in breast cancer. Biochim. Et Biophys. Acta Gene Regul. Mech. 2019. [CrossRef] [PubMed] 
13. Botti, G.; Giordano, A.; Feroce, F.; De Chiara, A.R.; Cantile, M. Noncoding RNAs as circulating biomarkers in osteosarcoma patients. J. Cell. Physiol. 2019, 234, 19249-19255. [CrossRef] [PubMed]

14. Zhou, Y.; Li, Y.; Wang, N.; Li, X.; Zheng, J.; Ge, L. UPF1 inhibits the hepatocellular carcinoma progression by targeting long non-coding RNA UCA1. Sci. Rep. 2019, 9, 6652. [CrossRef] [PubMed]

15. Tano, K.; Akimitsu, N. Long non-coding RNAs in cancer progression. Front. Genet. 2012, 3, 219. [CrossRef] [PubMed]

16. Su, G.; He, Q.; Wang, J. Clinical values of long non-coding rnas in bladder cancer: A systematic review. Front. Physiol. 2018, 9, 652. [CrossRef]

17. Shafiee, M.; Aleyasin, S.A.; Vasei, M.; Semnani, S.S.; Mowla, S.J. Down-regulatory effects of miR-211 on long non-coding RNA SOX2OT and SOX2 genes in esophageal squamous cell carcinoma. Cell J. 2016, 17, 593-600.

18. Song, H.; Xu, D.; Shi, P.; He, B.; Li, Z.; Ji, Y.; Agbeko, C.K.; Wang, J. Upregulated circ RNA hsa_circ_0000337 promotes cell proliferation, migration, and invasion of esophageal squamous cell carcinoma. Cancer Manag. Res. 2019, 11, 1997-2006. [CrossRef]

19. Sugihara, H.; Ishimoto, T.; Miyake, K.; Izumi, D.; Baba, Y.; Yoshida, N.; Watanabe, M.; Baba, H. Noncoding RNA expression aberration is associated with cancer progression and is a potential biomarker in esophageal squamous cell carcinoma. Int. J. Mol. Sci. 2015, 16, 27824-27834. [CrossRef]

20. Chen, M.; Liu, P.; Chen, Y.; Chen, Z.; Shen, M.; Liu, X.; Li, X.; Li, A.; Lin, Y.; Yang, R.; et al. Long noncoding RNA FAM201A mediates the radiosensitivity of esophageal squamous cell cancer by regulating ATM and mTOR expression via miR-101. Front. Genet. 2018, 9, 611. [CrossRef]

21. Fan, L.; Cao, Q.; Liu, J.; Zhang, J.; Li, B. Circular RNA profiling and its potential for esophageal squamous cell cancer diagnosis and prognosis. Mol. Cancer 2019, 18, 16. [CrossRef] [PubMed]

22. Salzman, J.; Gawad, C.; Wang, P.L.; Lacayo, N.; Brown, P.O. Circular RNAs are the predominant transcript isoform from hundreds of human genes in diverse cell types. PLoS ONE 2012, 7, e30733. [CrossRef] [PubMed]

23. Greene, J.; Baird, A.M.; Brady, L.; Lim, M.; Gray, S.G.; McDermott, R.; Finn, S.P. Circular RNAs: biogenesis, function and role in human diseases. Front. Mol. Biosci. 2017, 4, 38. [CrossRef] [PubMed]

24. Bach, D.H.; Lee, S.K.; Sood, A.K. Circular RNAs in cancer. Mol. Ther. Nucleic Acids 2019, 16, 118-129. [CrossRef]

25. Meng, S.; Zhou, H.; Feng, Z.; Xu, Z.; Tang, Y.; Li, P.; Wu, M. CircRNA: Functions and properties of a novel potential biomarker for cancer. Mol. Cancer 2017, 16, 94. [CrossRef]

26. Zhang, H.D.; Jiang, L.H.; Sun, D.W.; Hou, J.C.; Ji, Z.L. CircRNA: A novel type of biomarker for cancer. Breast Cancer 2018, 25, 1-7. [CrossRef]

27. Shi, N.; Shan, B.; Gu, B.; Song, Y.; Chu, H.; Qian, L. Circular RNA circ-PRKCI functions as a competitive endogenous RNA to regulate AKT3 expression by sponging miR-3680-3p in esophageal squamous cell carcinoma. J. Cell. Biochem. 2019, 120, 10021-10030. [CrossRef] [PubMed]

28. Cao, S.; Chen, G.; Yan, L.; Li, L.; Huang, X. Contribution of dysregulated circRNA_100876 to proliferation and metastasis of esophageal squamous cell carcinoma. Oncotargets Ther. 2018, 11, 7385-7394. [CrossRef]

29. Liu, H.; Ren, G.; Zhu, L.; Liu, X.; He, X. The upregulation of miRNA-146a inhibited biological behaviors of ESCC through inhibition of IRS2. Tumour Biol. J. Int. Soc. Oncodev. Biol. Med. 2016, 37, 4641-4647. [CrossRef] [PubMed]

30. Hemmatzadeh, M.; Mohammadi, H.; Karimi, M.; Musavishenas, M.H.; Baradaran, B. Differential role of microRNAs in the pathogenesis and treatment of Esophageal cancer. Biomed. Pharmacother. Biomed. Pharmacother. 2016, 82, 509-519. [CrossRef] [PubMed]

31. Zhang, E.; Han, L.; Yin, D.; He, X.; Hong, L.; Si, X.; Qiu, M.; Xu, T.; De, W.; Xu, L.; et al. H3K27 acetylation activated-long non-coding RNA CCAT1 affects cell proliferation and migration by regulating SPRY4 and HOXB13 expression in esophageal squamous cell carcinoma. Nucleic Acids Res. 2017, 45, 3086-3101. [CrossRef] [PubMed]

32. Wang, N.; Wang, J.; Meng, X.; Li, T.; Wang, S.; Bao, Y. The pharmacological effects of spatholobi caulis tannin in cervical cancer and its precise therapeutic effect on related circRNA. Mol. Ther. Oncolytics 2019, 14, 121-129. [CrossRef] [PubMed]

33. Qiao, G.; Dai, C.; He, Y.; Shi, J.; Xu, C. Effects of miR106b3p on cell proliferation and epithelialmesenchymal transition, and targeting of ZNRF3 in esophageal squamous cell carcinoma. Int. J. Mol. Med. 2019, 43, 1817-1829. [PubMed] 
34. Eichelmann, A.K.; Matuszcak, C.; Lindner, K.; Haier, J.; Hussey, D.J.; Hummel, R. Complex role of miR-130a-3p and miR-148a-3p balance on drug resistance and tumor biology in esophageal squamous cell carcinoma. Sci. Rep. 2018, 8, 17553. [CrossRef]

35. Huang, H.; Xu, Y.; Guo, Z.; Chen, X.; Ji, S.; Xu, Z. MicroRNA-133b inhibits cell proliferation and promotes apoptosis by targeting cullin $4 \mathrm{~B}$ in esophageal squamous cell carcinoma. Exp. Ther. Med. 2018, 15, 3743-3750. [CrossRef]

36. Park, M.; Yoon, H.J.; Kang, M.C.; Kwon, J.; Lee, H.W. MiR-338-5p enhances the radiosensitivity of esophageal squamous cell carcinoma by inducing apoptosis through targeting survivin. Sci. Rep. 2017, 7, 10932. [CrossRef]

37. Luo, H.L.; Huang, M.D.; Guo, J.N.; Fan, R.H.; Xia, X.T.; He, J.D.; Chen, X.F. AFAP1-AS1 is upregulated and promotes esophageal squamous cell carcinoma cell proliferation and inhibits cell apoptosis. Cancer Med. 2016, 5, 2879-2885. [CrossRef]

38. Chen, W.; Zhang, Y.; Wang, H.; Pan, T.; Zhang, Y.; Li, C. LINC00473/miR-374a-5p regulates esophageal squamous cell carcinoma via targeting SPIN1 to weaken the effect of radiotherapy. J. Cell. Biochem. 2019, 120, 14562-14572. [CrossRef]

39. Tang, Y.; Liu, J.H.; Shi, Z.X.; Li, Z.; Liu, H.T.; Lu, P. MicroRNA-133b suppresses cell proliferation and invasion of esophageal squamous cell carcinoma via downregulating TAGLN2 expression. Zhonghua Zhong Liu Za Zhi Chin. J. Oncol. 2019, 41, 91-96.

40. Ma, Q. MiR-219-5p suppresses cell proliferation and cell cycle progression in esophageal squamous cell carcinoma by targeting CCNA2. Cell. Mol. Biol. Lett. 2019, 24, 4. [CrossRef]

41. Zhang, J.; Fa, X.; Zhang, Q. MicroRNA206 exerts antioncogenic functions in esophageal squamous cell carcinoma by suppressing the cMet/AKT/mTOR pathway. Mol. Med. Rep. 2019, 19, 1491-1500. [PubMed]

42. Yu, H.X.; Wang, X.L.; Zhang, L.N.; Zhang, J.; Zhao, W. MicroRNA-384 inhibits the progression of esophageal squamous cell carcinoma through blockade of the LIMK1/cofilin signaling pathway by binding to LIMK1. Biomed. Pharmacother. Biomed. Pharmacother. 2019, 109, 751-761. [CrossRef] [PubMed]

43. Liu, Y.; Tang, Y.; Li, P. Inhibitory effect of microRNA-455-5p on biological functions of esophageal squamous cell carcinoma Eca109 cells via Rab31. Exp. Ther. Med. 2018, 16, 4959-4966. [CrossRef] [PubMed]

44. Jin, J.; Guo, T.; Guo, Y.; Liu, J.; Qu, F.; He, Y. Methylationassociated silencing of miR128 promotes the development of esophageal cancer by targeting COX2 in areas with a high incidence of esophageal cancer. Int. J. Oncol. 2019, 54, 644-654. [PubMed]

45. Mei, L.L.; Wang, W.J.; Qiu, Y.T.; Xie, X.F.; Bai, J.; Shi, Z.Z. miR-145-5p Suppresses Tumor Cell Migration, Invasion and Epithelial to Mesenchymal Transition by Regulating the Sp1/NF-kappaB Signaling Pathway in Esophageal Squamous Cell Carcinoma. Int. J. Mol. Sci. 2017, 18, 1833. [CrossRef] [PubMed]

46. Shimonosono, M.; Idichi, T.; Seki, N.; Yamada, Y.; Arai, T.; Arigami, T.; Sasaki, K.; Omoto, I.; Uchikado, Y.; Kita, Y.; et al. Molecular pathogenesis of esophageal squamous cell carcinoma: Identification of the antitumor effects of miR1453p on gene regulation. Int. J. Oncol. 2019, 54, 673-688. [CrossRef]

47. Lu, Y.F.; Yu, J.R.; Yang, Z.; Zhu, G.X.; Gao, P.; Wang, H.; Chen, S.Y.; Zhang, J.; Liu, M.Y.; Niu, Y.; et al. Promoter hypomethylation mediated upregulation of MicroRNA-10b-3p targets FOXO3 to promote the progression of esophageal squamous cell carcinoma (ESCC). J. Exp. Clin. Cancer Res. 2018, 37, 301. [CrossRef] [PubMed]

48. Yuan, R.B.; Zhang, S.H.; He, Y.; Zhang, X.Y.; Zhang, Y.B. MiR-874-3p is an independent prognostic factor and functions as an anti-oncomir in esophageal squamous cell carcinoma via targeting STAT3. Eur. Rev. Med. Pharmacol. Sci. 2018, 22, 7265-7273.

49. Liu, Y.; Wang, X.; Jiang, X.; Yan, P.; Zhan, L.; Zhu, H.; Wang, T.; Wen, J. Tumor-suppressive microRNA-10a inhibits cell proliferation and metastasis by targeting Tiam1 in esophageal squamous cell carcinoma. J. Cell. Biochem. 2018, 120, 7845-7857. [CrossRef]

50. Sun, C.; Zhang, X.; Chen, Y.; Jia, Q.; Yang, J.; Shu, Y. MicroRNA-365 suppresses cell growth and invasion in esophageal squamous cell carcinoma by modulating phosphoserine aminotransferase 1. Cancer Manag. Res. 2018, 10, 4581-4590. [CrossRef] [PubMed]

51. Su, H.; Wu, Y.; Fang, Y.; Shen, L.; Fei, Z.; Xie, C.; Chen, M. MicroRNA301a targets WNT1 to suppress cell proliferation and migration and enhance radiosensitivity in esophageal cancer cells. Oncol. Rep. 2019, 41, 599-607. [PubMed] 
52. Meng, L.; Liu, F.; Ju, Y.; Ding, P.; Liu, S.; Chang, S.; Liu, S.; Zhang, Y.; Lian, Y.; Gu, L.; et al. Tumor suppressive miR-6775-3p inhibits ESCC progression through forming a positive feedback loop with p53 via MAGE-A family proteins. Cell Death Dis. 2018, 9, 1057. [CrossRef] [PubMed]

53. Jiao, W.; Zhang, J.; Wei, Y.; Feng, J.; Ma, M.; Zhao, H.; Wang, L.; Jiao, W. MiR-139-5p regulates VEGFR and downstream signaling pathways to inhibit the development of esophageal cancer. Dig. Liver Dis. Off. J. Ital. Soc. Gastroenterol. Ital. Assoc. Study Liver 2019, 51, 149-156. [CrossRef] [PubMed]

54. Zhao, Y.; Wang, Y.; Xing, G. miR-516b functions as a tumor suppressor by directly modulating CCNG1 expression in esophageal squamous cell carcinoma. Biomed. Pharmacother. Biomed. Pharmacother. 2018, 106, 1650-1660. [CrossRef] [PubMed]

55. Jiang, T.; Liu, J.; Mu, J. Downregulation of microRNA449a5p promotes esophageal squamous cell carcinoma cell proliferation via cyclin D1 regulation. Mol. Med. Rep. 2018, 18, 848-854. [PubMed]

56. Fan, Y.X.; Bian, X.H.; Qian, P.D.; Chen, Z.Z.; Wen, J.; Luo, Y.H.; Yan, P.W.; Zhang, Q. MicroRNA-125b inhibits cell proliferation and induces cell apoptosis in esophageal squamous cell carcinoma by targeting BMF. Oncol. Rep. 2018, 40, 61-72. [CrossRef]

57. Shi, Q.; Wang, Y.; Mu, Y.; Wang, X.; Fan, Q. MiR-433-3p Inhibits Proliferation and Invasion of Esophageal Squamous Cell Carcinoma by Targeting GRB2. Cell. Physiol. Biochem. Int. J. Exp. Cell. Physiol. Biochem. Pharmacol. 2018, 46, 2187-2196. [CrossRef] [PubMed]

58. Chen, M.; Xia, Y.; Tan, Y.; Jiang, G.; Jin, H.; Chen, Y. Downregulation of microRNA-370 in esophageal squamous-cell carcinoma is associated with cancer progression and promotes cancer cell proliferation via upregulating PIN1. Gene 2018, 661, 68-77. [CrossRef]

59. Liu, W.; Li, M.; Chen, X.; Zhu, S.; Shi, H.; Zhang, D.; Cheng, C.; Li, B. MicroRNA-1 suppresses proliferation, migration and invasion by targeting Notch2 in esophageal squamous cell carcinoma. Sci. Rep. 2018, 8, 5183. [CrossRef]

60. Qi, B.; Wang, Y.; Chen, Z.J.; Li, X.N.; Qi, Y.; Yang, Y.; Cui, G.H.; Guo, H.Z.; Li, W.H.; Zhao, S. Down-regulation of miR-30a-3p/5p promotes esophageal squamous cell carcinoma cell proliferation by activating the Wnt signaling pathway. World J. Gastroenterol. 2017, 23, 7965-7977. [CrossRef]

61. Cui, X.B.; Peng, H.; Li, R.R.; Mu, J.Q.; Yang, L.; Li, N.; Liu, C.X.; Hu, J.M.; Li, S.G.; Wei, Y.; et al. MicroRNA-34a functions as a tumor suppressor by directly targeting oncogenic PLCE1 in Kazakh esophageal squamous cell carcinoma. Oncotarget 2017, 8, 92454-92469. [CrossRef]

62. Wang, K.; Li, J.; Xiong, G.; He, G.; Guan, X.; Yang, K.; Bai, Y. Negative regulation of lncRNA GAS5 by miR-196a inhibits esophageal squamous cell carcinoma growth. Biochem. Biophys. Res. Commun. 2018, 495, 1151-1157. [CrossRef] [PubMed]

63. Mei, L.L.; Wang, W.J.; Qiu, Y.T.; Xie, X.F.; Bai, J.; Shi, Z.Z. miR-125b-5p functions as a tumor suppressor gene partially by regulating HMGA2 in esophageal squamous cell carcinoma. PLoS ONE 2017, 12, e0185636. [CrossRef] [PubMed]

64. Zhang, J.H.; Xia, H.B. Lentiviral-mediated overexpression of MicroRNA-141 promotes cell Proliferation and inhibits apoptosis in human esophageal squamous cell carcinoma. Recent Pat. Anti-Cancer Drug Discov. 2019, 14, 170-176. [CrossRef] [PubMed]

65. Chen, X.; Cai, S.; Li, B.; Zhang, X.; Li, W.; Liang, H.; Cao, X.; Wang, L.; Wu, Z. MicroRNA21 regulates the biological behavior of esophageal squamous cell carcinoma by targeting RASA1. Oncol. Rep. 2019, 41, 1627-1637. [PubMed]

66. Wen, J.; Hu, Y.; Liu, Q.; Ling, Y.; Zhang, S.; Luo, K.; Xie, X.; Fu, J.; Yang, H. miR-424 coordinates multilayered regulation of cell cycle progression to promote esophageal squamous cell carcinoma cell proliferation. EBioMedicine 2018, 37, 110-124. [CrossRef] [PubMed]

67. Xiao, Q.; Chen, T.; Wu, Y.; Wu, W.; Xu, Y.; Gong, Z.; Chen, S. MicroRNA6753p promotes esophageal squamous cell cancer cell migration and invasion. Mol. Med. Rep. 2018, 18, 3631-3640. [PubMed]

68. Zhao, H.; Diao, C.; Wang, X.; Xie, Y.; Liu, Y.; Gao, X.; Han, J.; Li, S. MiR-543 promotes migration, invasion and epithelial-mesenchymal transition of esophageal cancer cells by targeting phospholipase A2 group IVA. Cell. Physiol. Biochem. Int. J. Exp. Cell. Physiol. Biochem. Pharmacol. 2018, 48, 1595-1604. [CrossRef]

69. Zhang, Y.; Ren, S.; Yuan, F.; Zhang, K.; Fan, Y.; Zheng, S.; Gao, Z.; Zhao, J.; Mu, T.; Zhao, S.; et al. miR-135 promotes proliferation and stemness of oesophageal squamous cell carcinoma by targeting RERG. Artif. Cells Nanomed. Biotechnol. 2018, 46, 1210-1219. [CrossRef] 
70. Zhang, J.; Zhang, Y.; Tan, X.; Zhang, Q.; Liu, C.; Zhang, Y. MiR-23b-3p induces the proliferation and metastasis of esophageal squamous cell carcinomas cells through the inhibition of EBF3. Acta Biochim. Biophys. Sin. 2018, 50, 605-614. [CrossRef]

71. Xu, J.; Pan, X.; Hu, Z. MiR-502 mediates esophageal cancer cell TE1 proliferation by promoting AKT phosphorylation. Biochem. Biophys. Res. Commun. 2018, 501, 119-123. [CrossRef] [PubMed]

72. Li, X.; Chen, D.; Li, M.; Gao, X.; Shi, G.; Zhao, H. The CADM2/Akt pathway is involved in the inhibitory effect of miR-21-5p downregulation on proliferation and apoptosis in esophageal squamous cell carcinoma cells. Chem. Biol. Interact. 2018, 288, 76-82. [CrossRef] [PubMed]

73. Chen, Z.; Lin, J.; Wu, S.; Xu, C.; Chen, F.; Huang, Z. Up-regulated miR-548k promotes esophageal squamous cell carcinoma progression via targeting long noncoding RNA-LET. Exp. Cell Res. 2018, 362, 90-101. [CrossRef] [PubMed]

74. Zhang, Y.; Jin, X.; Wang, Z.; Zhang, X.; Liu, S.; Liu, G. Downregulation of SNHG1 suppresses cell proliferation and invasion by regulating Notch signaling pathway in esophageal squamous cell cancer. Cancer Biomark. Sect. A Dis. Markers 2017, 21, 89-96. [CrossRef] [PubMed]

75. Yan, Y.; Fan, Q.; Wang, L.; Zhou, Y.; Li, J.; Zhou, K. LncRNA Snhg1, a non-degradable sponge for miR-338, promotes expression of proto-oncogene CST3 in primary esophageal cancer cells. Oncotarget 2017, 8, 35750-35760. [CrossRef]

76. Zhang, Y.; Li, R.; Ding, X.; Zhang, K.; Qin, W. Upregulation of long non-coding RNA SNHG6 promote esophageal squamous cell carcinoma cell malignancy and its diagnostic value. Am. J. Transl. Res. 2019, 11, 1084-1091.

77. Zhang, K.; Chen, J.; Song, H.; Chen, L.B. SNHG16/miR-140-5p axis promotes esophagus cancer cell proliferation, migration and EMT formation through regulating ZEB1. Oncotarget 2018, 9, 1028-1040. [CrossRef]

78. Han, G.H.; Lu, K.J.; Wang, P.; Ye, J.; Ye, Y.Y.; Huang, J.X. LncRNA SNHG16 predicts poor prognosis in ESCC and promotes cell proliferation and invasion by regulating Wnt/beta-catenin signaling pathway. Eur. Rev. Med. Pharmacol. Sci. 2018, 22, 3795-3803.

79. Ma, J.; Li, T.F.; Han, X.W.; Yuan, H.F. Downregulated MEG3 contributes to tumour progression and poor prognosis in oesophagal squamous cell carcinoma by interacting with miR-4261, downregulating DKK2 and activating the Wnt/beta-catenin signalling. Artif. Cells Nanomed. Biotechnol. 2019, 47, 1513-1523. [CrossRef]

80. Zhang, S.; Liang, Y.; Wu, Y.; Chen, X.; Wang, K.; Li, J.; Guan, X.; Xiong, G.; Yang, K.; Bai, Y. Upregulation of a novel lncRNA LINC01980 promotes tumor growth of esophageal squamous cell carcinoma. Biochem. Biophys. Res. Commun. 2019, 513, 73-80. [CrossRef]

81. Li, W.; Zhang, L.; Guo, B.; Deng, J.; Wu, S.; Li, F.; Wang, Y.; Lu, J.; Zhou, Y. Exosomal FMR1-AS1 facilitates maintaining cancer stem-like cell dynamic equilibrium via TLR7/NFkappaB/c-Myc signaling in female esophageal carcinoma. Mol. Cancer 2019, 18, 22. [CrossRef] [PubMed]

82. Wang, M.; Li, Y.; Yang, Y.; Liu, X.; Zang, M.; Li, Y.; Yang, K.; Yang, W.; Zhang, S. Long noncoding RNA DLX6AS1 is associated with malignant progression and promotes proliferation and invasion in esophageal squamous cell carcinoma. Mol. Med. Rep. 2019, 19, 1942-1950. [PubMed]

83. Zhong, Y.B.; Shan, A.J.; Lv, W.; Wang, J.; Xu, J.Z. Long non-coding RNA LINC00675 inhibits tumorigenesis and EMT via repressing Wnt/beta-catenin signaling in esophageal squamous cell carcinoma. Eur. Rev. Med. Pharmacol. Sci. 2018, 22, 8288-8297. [PubMed]

84. Wang, Z.; Ren, B.; Huang, J.; Yin, R.; Jiang, F.; Zhang, Q. LncRNA DUXAP10 modulates cell proliferation in esophageal squamous cell carcinoma through epigenetically silencing p21. Cancer Biol. Ther. 2018, 19, 998-1005. [CrossRef]

85. Wang, B.; Liang, T.; Li, J. Long noncoding RNA LINC01296 is associated with poor prognosis in ESCC and promotes ESCC cell proliferation, migration and invasion. Eur. Rev. Med. Pharmacol. Sci. 2018, 22, 4524-4531.

86. Shi, H.; Shi, J.; Zhang, Y.; Guan, C.; Zhu, J.; Wang, F.; Xu, M.; Ju, Q.; Fang, S.; Jiang, M. Long non-coding RNA DANCR promotes cell proliferation, migration, invasion and resistance to apoptosis in esophageal cancer. $J$. Thorac. Dis. 2018, 10, 2573-2582. [CrossRef]

87. Wu, Y.; Chen, X.; Liang, Y.; Li, J.; Zhang, K.; Dai, L.; Guan, X.; Wang, K.; Bai, Y. Overexpression of long non-coding RNA SOX2OT promotes esophageal squamous cell carcinoma growth. Cancer Cell Int. 2018, 18, 76. [CrossRef] 
88. Li, Y.; Li, J.; Luo, M.; Zhou, C.; Shi, X.; Yang, W.; Lu, Z.; Chen, Z.; Sun, N.; He, J. Novel long noncoding RNA NMR promotes tumor progression via NSUN2 and BPTF in esophageal squamous cell carcinoma. Cancer Lett. 2018, 430, 57-66. [CrossRef]

89. Sun, K.; Zhao, X.; Wan, J.; Yang, L.; Chu, J.; Dong, S.; Yin, H.; Ming, L.; He, F. The diagnostic value of long non-coding RNA MIR31HG and its role in esophageal squamous cell carcinoma. Life Sci. 2018, 202, 124-130. [CrossRef]

90. Zong, M.Z.; Shao, Q.; An, X.S. Expression and prognostic significance of long noncoding RNA AK001796 in esophageal squamous cell carcinoma. Eur. Rev. Med. Pharmacol. Sci. 2019, 23, 181-186.

91. Xie, J.J.; Jiang, Y.Y.; Jiang, Y.; Li, C.Q.; Lim, M.C.; An, O.; Mayakonda, A.; Ding, L.W.; Long, L.; Sun, C.; et al. Super-enhancer-driven long non-coding RNA LINC01503, regulated by TP63, is over-expressed and oncogenic in squamous cell carcinoma. Gastroenterology 2018, 154, 2137-2151.e1. [CrossRef] [PubMed]

92. Yoon, J.H.; You, B.H.; Park, C.H.; Kim, Y.J.; Nam, J.W.; Lee, S.K. The long noncoding RNA LUCAT1 promotes tumorigenesis by controlling ubiquitination and stability of DNA methyltransferase 1 in esophageal squamous cell carcinoma. Cancer Lett. 2018, 417, 47-57. [CrossRef] [PubMed]

93. Wang, L.; Yu, X.; Zhang, Z.; Pang, L.; Xu, J.; Jiang, J.; Liang, W.; Chai, Y.; Hou, J.; Li, F. Linc-ROR promotes esophageal squamous cell carcinoma progression through the derepression of SOX9. J. Exp. Clin. Cancer Res. 2017, 36, 182. [CrossRef] [PubMed]

94. Ma, J.; Fan, Y.; Feng, T.; Chen, F.; Xu, Z.; Li, S.; Lin, Q.; He, X.; Shi, W.; Liu, Y.; et al. HOTAIR regulates HK2 expression by binding endogenous miR-125 and miR-143 in oesophageal squamous cell carcinoma progression. Oncotarget 2017, 8, 86410-86422. [CrossRef]

95. Wu, X.; Dinglin, X.; Wang, X.; Luo, W.; Shen, Q.; Li, Y.; Gu, L.; Zhou, Q.; Zhu, H.; Li, Y.; et al. Long noncoding RNA XIST promotes malignancies of esophageal squamous cell carcinoma via regulation of miR-101/EZH2. Oncotarget 2017, 8, 76015-76028. [CrossRef]

96. Liu, H.; Zhen, Q.; Fan, Y. LncRNA GHET1 promotes esophageal squamous cell carcinoma cells proliferation and invasion via induction of EMT. Int. J. Biol. Markers 2017, 32, e403-e408. [CrossRef]

97. Li, Z.; Wu, X.; Gu, L.; Shen, Q.; Luo, W.; Deng, C.; Zhou, Q.; Chen, X.; Li, Y.; Lim, Z.; et al. Long non-coding RNA ATB promotes malignancy of esophageal squamous cell carcinoma by regulating miR-200b/Kindlin-2 axis. Cell Death Dis. 2017, 8, e2888. [CrossRef]

98. Lin, C.; Wang, Y.; Wang, Y.; Zhang, S.; Yu, L.; Guo, C.; Xu, H. Transcriptional and posttranscriptional regulation of HOXA13 by lncRNA HOTTIP facilitates tumorigenesis and metastasis in esophageal squamous carcinoma cells. Oncogene 2017, 36, 5392-5406. [CrossRef]

99. Li, P.D.; Hu, J.L.; Ma, C.; Ma, H.; Yao, J.; Chen, L.L.; Chen, J.; Cheng, T.T.; Yang, K.Y.; Wu, G.; et al. Upregulation of the long non-coding RNA PVT1 promotes esophageal squamous cell carcinoma progression by acting as a molecular sponge of miR-203 and LASP1. Oncotarget 2017, 8, 34164-34176. [CrossRef]

100. Yan, Y.; Li, S.; Wang, S.; Rubegni, P.; Tognetti, L.; Zhang, J.; Yan, L. Long noncoding RNA HAND2-AS1 inhibits cancer cell proliferation, migration, and invasion in esophagus squamous cell carcinoma by regulating microRNA-21. J. Cell. Biochem. 2019, 120, 9564-9571. [CrossRef]

101. Zhang, J.; Hu, S.L.; Qiao, C.H.; Ye, J.F.; Li, M.; Ma, H.M.; Wang, J.H.; Xin, S.Y.; Yuan, Z.L. LncRNA-NEF inhibits proliferation, migration and invasion of esophageal squamous-cell carcinoma cells by inactivating wnt/beta-catenin pathway. Eur. Rev. Med. Pharmacol. Sci. 2018, 22, 6824-6831. [PubMed]

102. Wang, G.; Sun, J.; Zhao, H.; Li, H. Long non-coding RNA (lncRNA) growth arrest specific 5 (GAS5) suppresses esophageal squamous cell carcinoma cell proliferation and migration by inactivating phosphatidylinositol 3-kinase (PI3K)/AKT/mammalian Target of Rapamycin (mTOR) signaling pathway. Med. Sci. Monit. Int. Med. J. Exp. Clin. Res. 2018, 24, 7689-7696. [CrossRef] [PubMed]

103. Ma, W.; Zhang, C.Q.; Li, H.L.; Gu, J.; Miao, G.Y.; Cai, H.Y.; Wang, J.K.; Zhang, L.J.; Song, Y.M.; Tian, Y.H.; et al. LncRNA FER1L4 suppressed cancer cell growth and invasion in esophageal squamous cell carcinoma. Eur. Rev. Med. Pharmacol. Sci. 2018, 22, 2638-2645. [PubMed]

104. Rong, J.; Wang, Q.; Zhang, Y.; Zhu, D.; Sun, H.; Tang, W.; Wang, R.; Shi, W.; Cao, X.F. Circ-DLG1 promotes the proliferation of esophageal squamous cell carcinoma. Oncotargets Ther. 2018, 11, 6723-6730. [CrossRef]

105. Huang, H.; Wei, L.; Qin, T.; Yang, N.; Li, Z.; Xu, Z. Circular RNA ciRS-7 triggers the migration and invasion of esophageal squamous cell carcinoma via miR-7/KLF4 and NF-kappaB signals. Cancer Biol. Ther. 2019, 20, 73-80. [CrossRef] [PubMed] 
106. Xia, W.; Qiu, M.; Chen, R.; Wang, S.; Leng, X.; Wang, J.; Xu, Y.; Hu, J.; Dong, G.; Xu, P.L.; et al. Circular RNA has_circ_0067934 is upregulated in esophageal squamous cell carcinoma and promoted proliferation. Sci. Rep. 2016, 6, 35576. [CrossRef]

107. Zhao, L.; Li, R.; Xu, S.; Li, Y.; Zhao, P.; Dong, W.; Liu, Z.; Zhao, Q.; Tan, B. Tumor suppressor miR-128-3p inhibits metastasis and epithelial-mesenchymal transition by targeting ZEB1 in esophageal squamous-cell cancer. Acta Biochim. Et Biophys. Sin. 2018, 50, 171-180. [CrossRef]

108. Ma, T.; Zhao, Y.; Lu, Q.; Lu, Y.; Liu, Z.; Xue, T.; Shao, Y. MicroRNA-30c functions as a tumor suppressor via targeting SNAI1 in esophageal squamous cell carcinoma. Biomed. Pharmacother. Biomed. Pharmacother. 2018, 98, 680-686. [CrossRef]

109. Wang, M.; Yang, Y.O.; Jin, Q.; Shang, L.; Zhang, J. Function of miR-25 in the invasion and metastasis of esophageal squamous carcinoma cells and bioinformatical analysis of the miR-106b-25 cluster. Exp. Ther. Med. 2018, 15, 440-446. [CrossRef]

110. Zuo, J.; Zhu, K.; Wang, Y.; Yu, Z. MicroRNA-34a suppresses invasion and metastatic in esophageal squamous cell carcinoma by regulating CD44. Mol. Cell. Biochem. 2018, 443, 139-149. [CrossRef]

111. Gao, Y.; Yi, J.; Zhang, K.; Bai, F.; Feng, B.; Wang, R.; Chu, X.; Chen, L.; Song, H. Downregulation of MiR-31 stimulates expression of LATS2 via the hippo pathway and promotes epithelial-mesenchymal transition in esophageal squamous cell carcinoma. J. Exp. Clin. Cancer Res. 2017, 36, 161. [CrossRef] [PubMed]

112. Li, B.; Xu, W.W.; Han, L.; Chan, K.T.; Tsao, S.W.; Lee, N.P.Y.; Law, S.; Xu, L.Y.; Li, E.M.; Chan, K.W.; et al. MicroRNA-377 suppresses initiation and progression of esophageal cancer by inhibiting CD133 and VEGF. Oncogene 2017, 36, 3986-4000. [CrossRef] [PubMed]

113. Ma, J.; Zhan, Y.; Xu, Z.; Li, Y.; Luo, A.; Ding, F.; Cao, X.; Chen, H.; Liu, Z. ZEB1 induced miR-99b/let-7e/miR-125a cluster promotes invasion and metastasis in esophageal squamous cell carcinoma. Cancer Lett. 2017, 398, 37-45. [CrossRef]

114. Zhang, Y.; Chen, W.; Pan, T.; Wang, H.; Zhang, Y.; Li, C. LBX2-AS1 is activated by ZEB1 and promotes the development of esophageal squamous cell carcinoma by interacting with HNRNPC to enhance the stability of ZEB1 and ZEB2 mRNAs. Biochem. Biophys. Res. Commun. 2019, 511, 566-572. [CrossRef] [PubMed]

115. Yao, J.; Shen, X.; Li, H.; Xu, J.; Shao, S.; Huang, J.X.; Lin, M. LncRNA-ECM is overexpressed in esophageal squamous cell carcinoma and promotes tumor metastasis. Oncol. Lett. 2018, 16, 3935-3942. [CrossRef] [PubMed]

116. Yang, L.; Sun, K.; Chu, J.; Qu, Y.; Zhao, X.; Yin, H.; Ming, L.; Wan, J.; He, F. Long non-coding RNA FTH1P3 regulated metastasis and invasion of esophageal squamous cell carcinoma through SP1/NF-kB pathway. Biomed. Pharmacother. Biomed. Pharmacother. 2018, 106, 1570-1577. [CrossRef]

117. Niu, G.; Zhuang, H.; Li, B.; Cao, G. Long noncoding RNA linc-UBC1 promotes tumor invasion and metastasis by regulating EZH2 and repressing E-cadherin in esophageal squamous cell carcinoma. J. B.U.ON. Off. J. Balk. Union Oncol. 2018, 23, 157-162.

118. Gao, G.D.; Liu, X.Y.; Lin, Y.; Liu, H.F.; Zhang, G.J. LncRNA CASC9 promotes tumorigenesis by affecting EMT and predicts poor prognosis in esophageal squamous cell cancer. Eur. Rev. Med. Pharmacol. Sci. 2018, 22, 422-429.

119. Shang, M.; Wang, X.; Zhang, Y.; Gao, Z.; Wang, T.; Liu, R. LincRNA-ROR promotes metastasis and invasion of esophageal squamous cell carcinoma by regulating miR-145/FSCN1. Oncotargets Ther. 2018, 11, 639-649. [CrossRef]

120. Wang, G.; Zhao, W.; Gao, X.; Zhang, D.; Li, Y.; Zhang, Y.; Li, W. HNF1AAS1 promotes growth and metastasis of esophageal squamous cell carcinoma by sponging miR214 to upregulate the expression of SOX-4. Int. J. Oncol. 2017, 51, 657-667. [CrossRef]

121. Chen, X.; Han, H.; Li, Y.; Zhang, Q.; Mo, K.; Chen, S. Upregulation of long noncoding RNA HOTTIP promotes metastasis of esophageal squamous cell carcinoma via induction of EMT. Oncotarget 2016, 7, 84480-84485. [CrossRef]

122. Yao, G.L.; Pan, C.F.; Xu, H.; Wei, K.; Liu, B.; Zhai, R.; Chen, Y.J. Long noncoding RNA RP11-766N7.4 functions as a tumor suppressor by regulating epithelial-mesenchymal transition in esophageal squamous cell carcinoma. Biomed. Pharmacother. Biomed. Pharmacother. 2017, 88, 778-785. [CrossRef] [PubMed] 
123. Li, B.; Hong, P.; Zheng, C.C.; Dai, W.; Chen, W.Y.; Yang, Q.S.; Han, L.; Tsao, S.W.; Chan, K.T.; Lee, N.P.Y.; et al. Identification of miR-29c and its Target FBXO31 as a Key Regulatory Mechanism in Esophageal Cancer Chemoresistance: Functional Validation and Clinical Significance. Theranostics 2019, 9, 1599-1613. [CrossRef] [PubMed]

124. Zhao, Y.; Ma, K.; Yang, S.; Zhang, X.; Wang, F.; Zhang, X.; Liu, H.; Fan, Q. MicroRNA-125a-5p enhances the sensitivity of esophageal squamous cell carcinoma cells to cisplatin by suppressing the activation of the STAT3 signaling pathway. Int. J. Oncol. 2018, 53, 644-658. [CrossRef] [PubMed]

125. Yu, Q.; Liu, Y.; Wen, C.; Zhao, Y.; Jin, S.; Hu, Y.; Wang, F.; Chen, L.; Zhang, B.; Wang, W.; et al. MicroRNA-1 inhibits tumorigenicity of esophageal squamous cell carcinoma and enhances sensitivity to gefitinib. Oncol. Lett. 2018, 15, 963-971. [CrossRef]

126. Zheng, R.; Liu, Y.; Zhang, X.; Zhao, P.; Deng, Q. miRNA-200c enhances radiosensitivity of esophageal cancer by cell cycle arrest and targeting P21. Biomed. Pharmacother. Biomed. Pharmacother. 2017, 90, 517-523. [CrossRef]

127. Chang, Z.W.; Jia, Y.X.; Zhang, W.J.; Song, L.J.; Gao, M.; Li, M.J.; Zhao, R.H.; Li, J.; Zhong, Y.L.; Sun, Q.Z.; et al. LncRNA-TUSC7/miR-224 affected chemotherapy resistance of esophageal squamous cell carcinoma by competitively regulating DESC1. J. Exp. Clin. Cancer Res. 2018, 37, 56. [CrossRef]

128. Chen, Y.; Liu, L.; Li, J.; Du, Y.; Wang, J.; Liu, J. Effects of long noncoding RNA (linc-VLDLR) existing in extracellular vesicles on the occurrence and multidrug resistance of esophageal cancer cells. Pathol. Res. Pract. 2019, 215, 470-477. [CrossRef]

129. Sun, Y.; Wang, J.; Pan, S.; Yang, T.; Sun, X.; Wang, Y.; Shi, X.; Zhao, X.; Guo, J.; Zhang, X. LINC00657 played oncogenic roles in esophageal squamous cell carcinoma by targeting miR-615-3p and JunB. Biomed. Pharmacother. Biomed. Pharmacother. 2018, 108, 316-324. [CrossRef]

130. Kang, M.; Ren, M.; Li, Y.; Fu, Y.; Deng, M.; Li, C. Exosome-mediated transfer of lncRNA PART1 induces gefitinib resistance in esophageal squamous cell carcinoma via functioning as a competing endogenous RNA. J. Exp. Clin. Cancer Res. 2018, 37, 171. [CrossRef]

131. Li, Z.; Zhou, Y.; Tu, B.; Bu, Y.; Liu, A.; Kong, J. Long noncoding RNA MALAT1 affects the efficacy of radiotherapy for esophageal squamous cell carcinoma by regulating Cks1 expression. J. Oral Pathol. Med. Off. Publ. Int. Assoc. Oral Pathol. Am. Acad. Oral Pathol. 2017, 46, 583-590. [CrossRef] [PubMed]

132. Li, S.P.; Su, H.X.; Zhao, D.; Guan, Q.L. Plasma miRNA-506 as a Prognostic Biomarker for Esophageal Squamous Cell Carcinoma. Med. Sci. Monit. Int. Med. J. Exp. Clin. Res. 2016, 22, 2195-2201. [CrossRef] [PubMed]

133. Jin, W.; Luo, W.; Fang, W.; Wang, Y.; Wang, L.; Shen, Q.; Liu, W.; Zhang, H. miR-145 expression level in tissue predicts prognosis of patients with esophageal squamous cell carcinoma. Pathol. Res. Pract. 2019, 215, 152401. [CrossRef] [PubMed]

134. Luo, H.S.; Wu, D.H. Identification of miR-375 as a potential prognostic biomarker for esophageal squamous cell cancer: A bioinformatics analysis based on TCGA and meta-analysis. Pathol. Res. Pract. 2019, 215, 512-518. [CrossRef] [PubMed]

135. Kiuchi, J.; Komatsu, S.; Imamura, T.; Nishibeppu, K.; Shoda, K.; Arita, T.; Kosuga, T.; Konishi, H.; Shiozaki, A.; Okamoto, K.; et al. Low levels of tumour suppressor miR-655 in plasma contribute to lymphatic progression and poor outcomes in oesophageal squamous cell carcinoma. Mol. Cancer 2019, 18, 2. [CrossRef] [PubMed]

136. Dong, Z.; Liang, X.; Wu, X.; Kang, X.; Guo, Y.; Shen, S.; Liang, J.; Guo, W. Promoter hypermethylation-mediated downregulation of tumor suppressor gene SEMA3B and lncRNA SEMA3B-AS1 correlates with progression and prognosis of esophageal squamous cell carcinoma. Clin. Exp. Metastasis 2019, 36, 225-241. [CrossRef] [PubMed]

137. Sadeghpour, S.; Ghorbian, S. Evaluation of the potential clinical prognostic value of lncRNA-BANCR gene in esophageal squamous cell carcinoma. Mol. Biol. Rep. 2019, 46, 991-995. [CrossRef] [PubMed]

138. Kang, K.; Huang, Y.H.; Li, H.P.; Guo, S.M. Expression of UCA1 and MALAT1 long-chain non-coding RNAs in esophageal squamous cell carcinoma tissues is predictive of patient prognosis. Arch. Med. Sci. AMS 2018, 14, 752-759. [CrossRef]

139. Bao, J.; Zhou, C.; Zhang, J.; Mo, J.; Ye, Q.; He, J.; Diao, J. Upregulation of the long noncoding RNA FOXD2-AS1 predicts poor prognosis in esophageal squamous cell carcinoma. Cancer Biomark. Sect. A Dis. Markers 2018, 21, 527-533. [CrossRef] 
140. Rupaimoole, R.; Slack, F.J. MicroRNA therapeutics: Towards a new era for the management of cancer and other diseases. Nat. Rev. Drug Discov. 2017, 16, 203-222. [CrossRef]

141. Cao, J.; Lv, W.; Wang, L.; Xu, J.; Yuan, P.; Huang, S.; He, Z.; Hu, J. Ricolinostat (ACY-1215) suppresses proliferation and promotes apoptosis in esophageal squamous cell carcinoma via miR-30d/PI3K/AKT/mTOR and ERK pathways. Cell Death Dis. 2018, 9, 817. [CrossRef]

142. Peng, W.X.; Koirala, P.; Mo, Y.Y. LncRNA-mediated regulation of cell signaling in cancer. Oncogene 2017, 36, 5661-5667. [CrossRef]

143. Li, Y.; Chen, D.; Gao, X.; Li, X.; Shi, G. LncRNA NEAT1 Regulates Cell Viability and Invasion in Esophageal Squamous Cell Carcinoma through the miR-129/CTBP2 Axis. Dis. Markers 2017, 2017, 5314649. [CrossRef] [PubMed]

144. Jiang, C.; Xu, D.; You, Z.; Xu, K.; Tian, W. Dysregulated circRNAs and ceRNA network in esophageal squamous cell carcinoma. Front. Biosci. 2019, 24, 277-290.

145. Diepenbruck, M.; Christofori, G. Epithelial-mesenchymal transition (EMT) and metastasis: Yes, no, maybe? Curr. Opin. Cell Biol. 2016, 43, 7-13. [CrossRef] [PubMed]

146. Lu, W.; Kang, Y. Epithelial-Mesenchymal Plasticity in Cancer Progression and Metastasis. Dev. Cell 2019, 49, 361-374. [CrossRef]

147. Hiroyuki, K.; Masanobu, N. Treatments for esophageal cancer: A review. Gen. Thorac. Cardiovasc. Surg. 2013, 61, 330-335.

148. Haenisch, S.; Cascorbi, I. miRNAs as mediators of drug resistance. Epigenomics 2012, 4, 369-381. [CrossRef]

149. Chen, Q.N.; Wei, C.C.; Wang, Z.X.; Sun, M. Long non-coding RNAs in anti-cancer drug resistance. Oncotarget 2017, 8, 1925-1936. [CrossRef]

150. Wang, W.; Wei, C.; Li, P.; Wang, L.; Li, W.; Chen, K.; Zhang, J.; Zhang, W.; Jiang, G. Integrative analysis of mRNA and lncRNA profiles identified pathogenetic lncRNAs in esophageal squamous cell carcinoma. Gene 2018, 661, 169-175. [CrossRef]

151. Rao, D.D.; Vorhies, J.S.; Senzer, N.; Nemunaitis, J. siRNA vs. shRNA: Similarities and differences. Adv. Drug Deliv. Rev. 2009, 61, 746-759. [CrossRef] [PubMed]

152. Wu, Y.; Hu, L.; Liang, Y.; Li, J.; Wang, K.; Chen, X.; Meng, H.; Guan, X.; Yang, K.; Bai, Y. Up-regulation of lncRNA CASC9 promotes esophageal squamous cell carcinoma growth by negatively regulating PDCD4 expression through EZH2. Mol. Cancer 2017, 16, 150. [CrossRef] [PubMed]

153. Liang, Y.; Chen, X.; Wu, Y.; Li, J.; Zhang, S.; Wang, K.; Guan, X.; Yang, K.; Bai, Y. LncRNA CASC9 promotes esophageal squamous cell carcinoma metastasis through upregulating LAMC2 expression by interacting with the CREB-binding protein. Cell Death Differ. 2018, 25, 1980-1995. [CrossRef] [PubMed]

154. Anastasiadou, E.; Jacob, L.S.; Slack, F.J. Non-coding RNA networks in cancer. Nat. Rev. Cancer 2018, 18, 5-18. [CrossRef] [PubMed]

(C) 2019 by the authors. Licensee MDPI, Basel, Switzerland. This article is an open access article distributed under the terms and conditions of the Creative Commons Attribution (CC BY) license (http://creativecommons.org/licenses/by/4.0/). 